Original Research Paper

\title{
Sosialisasi Mitigasi Bencana Kepada Masyarakat Dan Pemasangan Plang Jalur Evakuasi di Desa Selengen Kecamatan Kayangan Kabupaten Lombok Utara
}

\author{
Irwan Jayadi, Nuri Aldhila Maqother, Renita Maeta Safwan, Ni Wayan Putri Widnyani. Isti \\ Fardila Aeni, Nisa Zuliyana Afriani, Helena Damayanti Insani, Fridallyn Marischa Justine Mebe, \\ Dimas Yanuar Perdana, Misfalatun, Sukmawati, Andi Cahyuni Candrawati, Ni Luh Tania Putri \\ Wijaya, Ines Kurnila Sari, Nuriadi \\ ${ }^{1}$ Universitas Mataram, Mataram, Indonesia
}

https://doi.org/10.29303/jpmpi.v3i2.1342

Sitasi: Mahardin., Fauzan, A., Muliadi \& Rahmah, N. (2022). Pembentukan Karakter Demokratis Melalui Pelaksanaan Metode Pembelajaran Kooperatif tipe Number Head Together pada Siswa Kelas XI SMK Negeri 1 Kota Bima. Jurnal Pengabdian Magister Pendidikan IPA, 5(1)

\section{Article history}

Received: 11 Januari 2022

Revised: 01 Februari 2022

Accepted: 07 Februari 2022

*Corresponding Author: Irwan Jayadi, Universitas Mataram Mataram, Indonesia;

Email:

kknplpdesaselengen@gmail.com

\section{Pendahuluan}

Bencana merupakan suatu fenomena yang tidak dapat dihindari begitu saja oleh manusia. Fenomena tersebut dapat terjadi setiap saat, secara tiba-tiba atau melalui proses yang berlangsung secara perlahan dimanapun dan kapanpun. UndangUndang No. 24 Tahun 2007 tentang Penanggulangan Bencana menyebutkan bahwa bencana merupakan peristiwa atau rangkaian peristiwa yang mengancam dan mengganggu kehidupan dan penghidupan masyarakat yang disebabkan baik oleh faktor alam dan/atau faktor nonalam maupun faktor manusia sehingga mengakibatkan timbulnya korban jiwa manusia, kerusakan lingkungan, kerugian harta benda, dan dampak psikologis. Bencana dibagi menjadi tiga yaitu bencana alam, bencana non alam, dan bencana sosial. Bencana alam merupakan suatu peristiwa yang berada di luar kontrol manusia dan datang tanpa diduga kapan, dimana, dan bagaimana bencana tersebut terjadi.

Indonesia disebut sebagai supermarket bencana yang artiya Indonesia memiliki potensi bencana dan mengalami berbagai jenis bencana. Secara geografis, Indonesia terletak pada dua samudra dan dua benua. Hal ini menyebabkan Indonesia mempunyai musim hujan dan musim kemarau serta menyebabkan daerah Indonesia memiliki cuaca yang selalu berubah-ubah. Secara geologis, letak Indonesia yang berada di pertemuan 
lempeng tektonik yaitu lempeng asia, lempeng australia, lempeng pasifik, dimana lempenganlempengan tadi saling bergesekan dan tak jarang menyebabkan gempa. Akibat dari letak Indonesia secara geografis dan secara geologis tersebut mengakibatkan Indonesia sangat berpotensi sekaligus rentan terhadap bencana seperti letusan gunung berapi, gempa bumi, tsunami, banjir, dan tanah longsor.

Desa Selengen merupakan salah satu bagian dari Wilayah Kecamatan Kayangan yan terletak di penghujung sebelah timur Kecamatan Kayangan yang jarak dari ibu Kota Kecamatan Kayangan \pm 5 KM sedangkan jarak dari ibu kota kabupaten \pm 27 KM dan jarak dari ibu kota Provinsi \pm 67 KM sedangkan Desa Selengen kalau di lihat dari segi geografisnya mempunyai posisi dan batasbatas wilayah sebagai berikut :

-Sebelah Utara: Berbatasan dengan Plores

-Sebelah Selata: Berbatasan dengan Hutan

- Sebelah Barat: Berbatasan dengan Desa Gumantar -Sebelah Timur: Berbatasan dengan Desa Mumbul Sari

Berdasarkan letak nya tersebut, desa selangan menjadi salah satu desa yang perlu dilakukan sosialisasi mitigasi bencana \& pemasangan portal tanggap bencana oleh karena itu KKN PLP Unram mengadakan sosialisasi mitigasi bencana alam yang menghadirkan bpbd sebagai narasumber dengan tujuan untuk kesiapsiagaan diri secara mandiri sebagai bentuk penguasaan dan pengetahuan untuk menyelamatkan diri dari potensi bencana alam dan KKN PLP Unram membuat portal tanggap bencana di desa selengen untuk mempermudah warga jika terjadi bencana alam para warga pendatang, warga local, dan wisatawan dapat dengan mudah menyelamatkan diri.

\section{Metode}

A. Waktu dan tempat pelaksanaan

1. Sosialisasi mitigasi bencana

Kegiatan sosialisasi dilakukan sebanyak dua kali, yang pertama dilaksanakan di SDN 2 Selengen pada tanggal 4 Desember 2021. Sosialisasi mitigasii bencana alam yang kedua dilaksanakan di aula kantor Desa pada tanggal 9 Desember 2021 di Desa Selengen Kecamatan Kayangan Kabupaten Lombok Utara
2. Pemasangan plang jalur evakuasi

Kegiatan pemasangan plang jalur evakuasi ini dilakukan mulai dari persiapan hingga pembuatan pada tanggal 6-20 Desember 2021 dan Pemasangan Plang jalur evakuasi dan titik kumpul dilakukan pada tanggal 23 Desember 2021 di beberapa dusun di desa selengen kecamatan kayangan kabupaten Lombok utara

B. Bahan-bahan produksi

Bahan-bahan yang di perlukan untuk pembuatan plang jalur evakuasi adalah kayu, papan, cat, kuas, paku, pasir, semen dan lainnnya.

C. Metode Pembuatan

Metode yang di gunakan dalam penelitian ini adalah metode kualitatif - deskriptif. KKN Unram menghadirkan BPBD sebagai narasumber untuk Pelaksanaan Sosialisasi Mitigasi Bencana Alam. Pengumpulan data dilakukan dengan menggunakan teknik wawancara, dokumentasi, dan observasi.

\section{Hasil dan Pembahasan}

Desa Selengen mempunyai 13 dusun, yaitu Dusun Dusun Tangge, Sambik jengkel timur, Lokok mandi, Sangiang, Dompo indah, Gerung perigi, Sambik jengkel barat, Gubuk baru, Selengen, Tampes, Lembah berora, Panggung barat dan Panggung timur. Sosialisasi mitigasi bencana di sekolah kami lakukan di SDN 2 Selengen yang mana lokasinya berada di dusun Tampes. Kegiatan di SDN 2 Selengen diikuti oleh para murid kelas 6. Peserta terlihat antusias mendengarkan sosialisasi dalam bentuk presentasi dan simulasi. Antusiasme ini dapat dilihat dari para siswa yang lancar menjawab pertanyaanpertanyaan yang diberikan mengenai materi, mendengarkan materi yang kami presentasikan dengan seksama, dan duduk tertib selama sosialisasi berlangsung. Sosialisasi mitigasi bencana yang selanjutnya kami lakukan di Aula Kantor Desa yang di hadiri oleh kepala dusun dan perwakilan 3 warga di setiap dusun di desa Selengen. Pada sosialisai kali ini kami 
mengundang BPBD sebagai narasumber untuk sosialisasi mitigasi bencana alam.

Pembuatan plang jalur evakuasi dan titik kumpul dipasang di beberapa dusun di desa Selengen. Terdapat 8 jalur evakuasi yang dipasang dimulai dari dusun Tampes, Gubug baru, Sambik jengel timur, Sambik jengkel perigi, dan Dompo indah. Terdapat dua titik kumpul yang kami pasang yang berada di dusun Dompo indah dan dusun Tampes.

Desa Selengen memiliki potensi tinggi terjadinya Gempa Bumi, Tsunami, dan Abrasi dikarenakan lokasi yang berada di dekat Gunung Rinjani dan Pantai. Oleh karena itu, Kkn PLP membuat jalur evakuasi untuk tiga bencana Alam ini dan dua titik kumpul untuk Gempa Bumi, Tsunami dan Abrasi.

Manfaat yang di yang di peroleh dari pembuatan plang jalur evakuasi ini untuk mempermudah warga jika terjadi bencana alam. Para warga pendatang, warga lokal, dan wisatawan dapat dengan mudah menyelamatkan diri ketika bencana terjadi.

Hasil dari kegiatan sosialisasi dan pembuatan portal tanggap bencana dapat dikatakan berhasil. Dikarenakan antusias masyarakat terhadap kegiatan yang diadakan dan partisipasi warga di setiap kegiatan yang kami adakan.

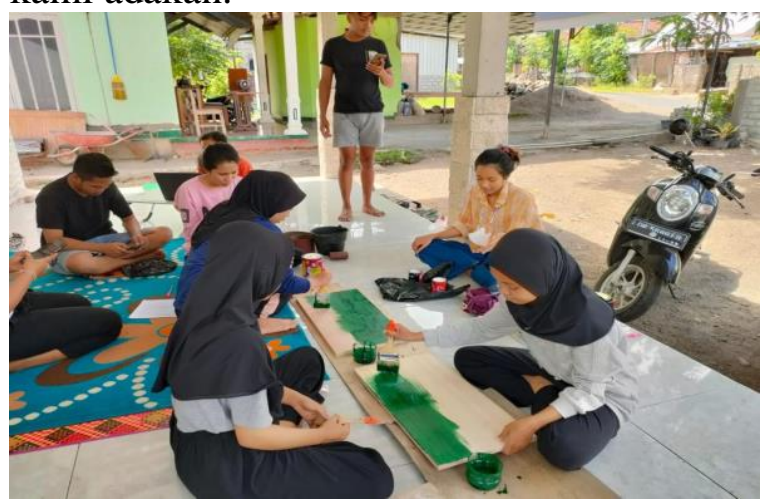

Figure 1. Proses pembuatan plang

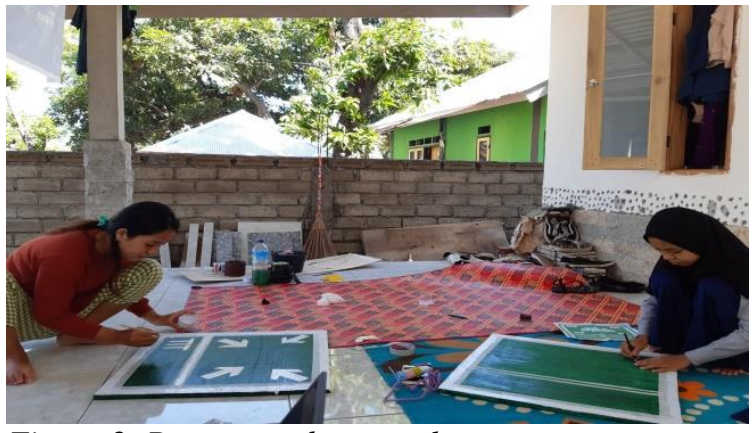

Figure 2. Proses pembuatan plang

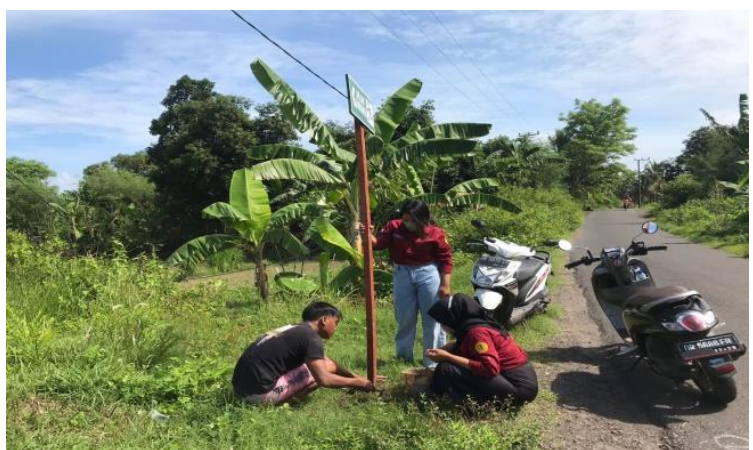

Figure 3. Pemasangan plang jalur evakuasi \& titik kumpul

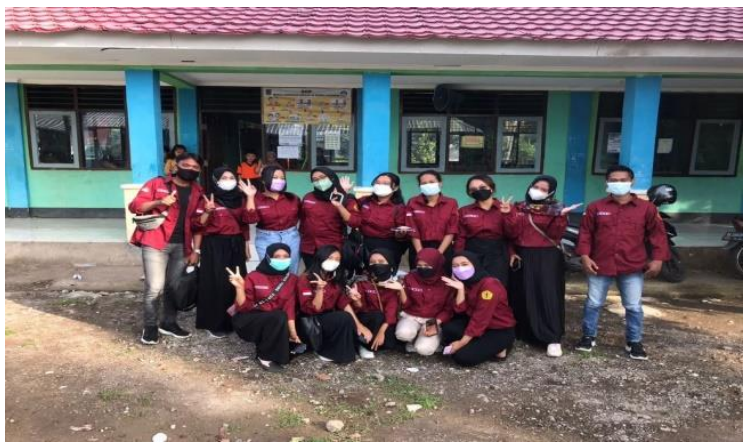

Figure 4. sosialisasi di SDN 2 Selengen

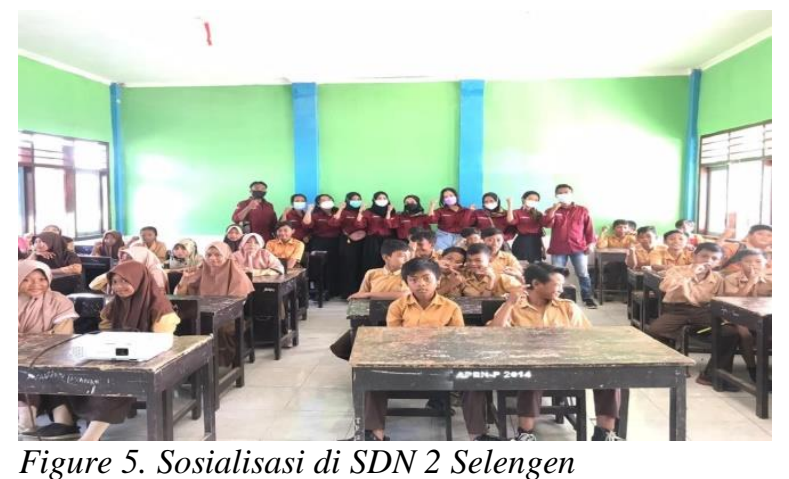

Figure 5. Sosialisasi di SDN 2 Selengen 


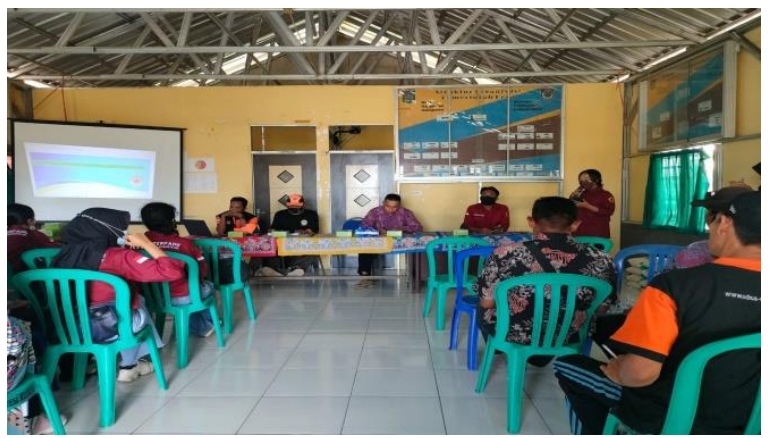

Figure 6. Sosialisasi di Aula Kantor Desa bersama $B P B D$

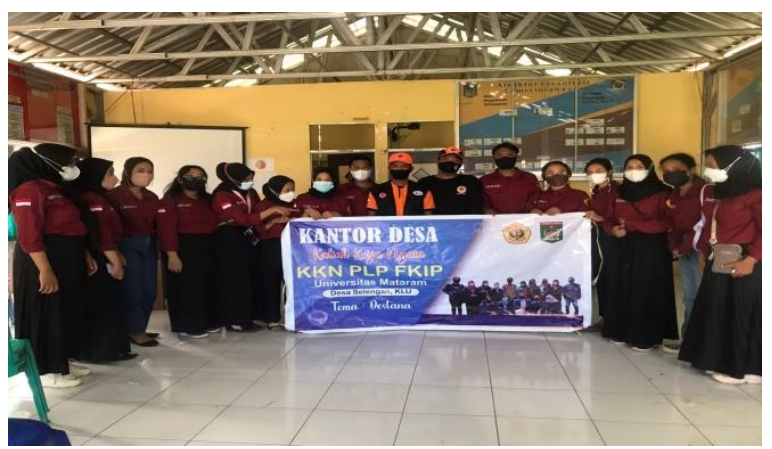

Figure 7. Sosialisasi di Aula Kantor Desa bersama $B P B D$

\section{Kesimpulan}

Berdasarkan hasil analisis dan evaluasi kegiatan sosialisasi mitigasi bencana kepada masyarakat dan pemasangan plang jalur evakuasi di desa selengen kecamatan kayangan kabupaten lombok utara yang menjadi kegiatan utama tim KKN PLP Unram 2021 dengan tema Desa Tanggap Bencana (Destana), maka dapat disimpulkan bahwa masyarakat di desa selengen telah memiliki kesiagaan dalam menghadapi bencana alam.

Kelancaran kegiatan kami tidak terlepas berkat bantuan berbagai pihak maka pada kesempatan ini penulis mengucapkan banyak terima kasih kepada yang terhormat: Rektor Universitas Mataram, ketua LPPM Universitas Mataram, kepada Desa Selengen, dan Kepala Dusun Tangge, Sambik jengkel timur, Lokok mandi, Sangiang, Dompo indah, Gerung perigi, Sambik jengkel barat, Gubuk baru, Selengen, Tampes, Lembah berora, Panggung barat dan Panggung timur, Tokoh masyarakat, dan semua pihak yang telah membantu mulai dari awal hingga akhir dari kegiatan ini

\section{Ucapan Terima Kasih}

Terima kasih kepada Dosen Pembimbing Lapangan Bapak Ahmad Fauzan S.Pd, M.Pd yang telah memberikan arahan, bimbingan, serta motivasi dalam pelaksanaan PLP FKIP, Universitas Mataram di SMK Negeri 1 Kota Bima. Ucapan terima kasih juga kami sampaikan kepada Kepala SMK Negeri 1 Kota Bima Ibu Ratnah S.Pi., M.Pd, Guru Pamong Bapak Drs. Mahardin dan seluruh komponen yang ada di SMK Negeri 1 Kota Bima yang telah membantu kami dalam menyelesaikan kegiatan ini dengan baik dari awal hingga akhir.

\section{Daftar Pustaka}

Afifuddin, dan Beni Ahmad Saebani.(2009). Metode Penelitian Kualitatif. Bandung: Pustaka Setia.

Sugiyono. (2012). Memahami Penelitian Kualitatif. Bandung : Alfabeta.

Undang-Undang No. 24 Tahun 2007 tentang Penanggulangan Bencana. 